Małgorzata Molęda-Zdziech

\title{
EWOLUCJA MODELI LOBBINGU - WPŁYW GOSPODARKI OPARTEJ NA INFORMACJACH I WIEDZY
}

\section{Wprowadzenie}

Celem opracowania jest analiza porównawcza modeli lobbingu (pluralistycznego - charakterystycznego dla Stanów Zjednoczonych, Wielkiej Brytanii i w pewnym stopniu Unii Europejskiej oraz neokorporatywistycznego - typowego dla krajów Europy Zachodniej i Polski) pod kątem zmian wywołanych rozwojem gospodarki opartej na informacjach i wiedzy, której szczególną formą jest wikinomia. Rozwój nowych technologii, a także zasady globalnej współpracy, stanowiące kluczowe elementy tej gospodarki, wpływają na wyłanianie się nowych strategii działań w lobbingu. Powoduje to ewoluowanie dotychczasowych modeli lobbingu w stronę lobbingu oddolnego (grassroots lobbing), który przyjmuje różne formy: od masowych demonstracji i manifestacji po działania w sieci, on-line, czyli cyberlobbing i dotyczy różnych form lobbingu: politycznego, gospodarczego czy społecznego.

\section{Instytucjonalizacja lobbingu w demokracji}

Wywieranie wpływu na decydentów przy użyciu legalnych metod, bo tak najczęściej definiuje się lobbing, to nieodłączna część współczesnej, zglobalizowanej rzeczywistości społeczno-politycznej.

Ujmując rzecz modelowo, obywatele, za pośrednictwem organizacji, stowarzyszeń itp. lub bezpośrednio, za pomocą lobbingu informują władzę o własnych potrzebach, mankamentach istniejących rozwiązań społecznych czy też alternatywnych rozwiązaniach. Umożliwia to przedstawicielom administracji publicznej i ustawodawcom dostosowanie stanowionego prawa, rozporządzeń i procedur do proponowanego/optymalnego wzoru. Dzięki temu mogą uniknąć błędów, a także korygować je. Tym samym rzecznictwo interesów może służyć racjonalizacji systemu prawnego. Legislatorzy zaś nie mogą ignorować proponowanych rozwiązań 
czy zgłaszanych zastrzeżeń, ponieważ rzecznictwo interesów jest też swoistą „siłą”, za którą kryje się opinia publiczna (np. w ramach akcji typu lobbing oddolny - grassroots lobbing ${ }^{1}$ ), czy organizacje biorące udział w procesie konsultacji, np. w ramach Komisji Trójstronnej. Opisany proces inaczej funkcjonuje w pluralistycznym modelu anglosaskim, korporatywistycznym, a inaczej w modelu typowym dla Unii Europejskiej, które zostały przedstawione w tabeli 1. Za szczególną formę lobbingu można uznać też dialog społeczny. W Unii Europejskiej dialog społeczny jest rozwijającym się procesem, w 1989 roku problematyka ta trafiła do fundamentalnych praw objętych przez Kartę podstawowych praw socjalnych. Wywieranie wpływu na unijnym forum stanowi pełnoprawną technikę. Należy do jednej z powszechnie obowiązujących form uczestnictwa w procesie decyzyjnym. Pozwoli to zrozumieć, że lobbing sensu stricto nie jest tożsamy z korupcją, ale może stanowić część systemu demokratycznego w procedurze podejmowania decyzji, obowiązkowych konsultacji, $\mathrm{w}$ formie np. dialogu społecznego.

Lobbing traktuję właśnie jako wprowadzenie w życie pewnych nowych reguł gry, które stanowią element zmiany społecznej, przejście od ładu kolektywnego do ładu liberalno-indywidualistycznego. Obu formom ładu towarzyszą różne metody i techniki lobbingowe. Charakteryzując ogólne warunki modelu analizy zmiany systemowej, należy pamiętać, że „wprowadzenie w życie nowych reguł napotyka bariery, ponieważ niedostatecznie zharmonizowane są wartości i cele społeczne, aktorzy jako ich nosiciele, metody działań, zasoby, jakie mają oni do dyspozycji, przestrzeń, w jakiej działają z okolicznościami czasu i miejsca”. ${ }^{2}$ Rzecznictwo interesów (advocacy), czyli lobbing o charakterze non profit organizacji pozarządowych to także pewna nowa w polskich realiach instytucja, polegająca na kształtowaniu się wzorów interakcji pomiędzy aktorami, którą można scharakteryzować, odwołując się do wyżej wymienionych czynników. W rozumieniu Northa „Instytucje to wymyślone przez ludzi ograniczenia, które strukturalizują ludzkie interakcje”. Są one kształtowane przez reguły formalne, np. prawa, konstytucje, regulaminy i „cały szereg struktur pomyślanych tak, by czynić świat mniej nieprzewidywalnym dla ustanawiających je osób". Uzupełniają je i modyfikują nieformalne normy zachowania,

\footnotetext{
1 Mających na celu dotarcie do jak największej liczby odbiorców. Dopiero potem, po nagłośnieniu akcji przez media, dociera się z takim przekazem do decydentów. „Tradycyjnie ujmowany jest [on, dialog społeczny - przypis mój, M.M.-Z.] jako mniej lub bardziej zinstytucjonalizowany sposób komunikowania się między władzą państwową (zwykle jej częścią wykonawczą) a różnymi podmiotami społecznymi reprezentującymi interesy znaczących odłamów społeczeństwa, których zasadniczą funkcją jest wzajemne przekazywanie sobie opinii oraz ustaleń dotyczących celów, instrumentów i strategii wdrażania jakiegoś rodzaju polityki publicznej”. B. Gąciarz, W. Pańków, Dialog społeczny po polsku - fikcja czy szansa, Instytut Spraw Publicznych, Warszawa 2001, s. 17.

2 W. Morawski, Zmiana instytucjonalna, PWN, Warszawa 1998, s. 15.

3 Ibidem, s. 59.

${ }^{4}$ Ibidem.
} 
które w istotny sposób rozszerzają, zmieniają, korygują formalne reguły gry. Ograniczenia nieformalne przyjmują formę np. normy zachowania, konwencji, narzuconych sobie kodów postępowania.

Trzecim, ostatnim elementem tworzącym instytucje jest system sankcji, określający sposób egzekwowania dwóch poprzednich: reguł formalnych i nieformalnych. Zdaniem Northa wszystkie wymienione elementy: ograniczenia formalne, nieformalne oraz system sankcji wyznaczają sposób funkcjonowania społeczeństwa i gospodarki. ${ }^{5}$

Proces instytucjonalizacji obejmuje dwie podstawowe fazy: utworzenia organizacji formalnych (obejmującą też ustanowienie ram prawnych) oraz fazę o charakterze normatywnym, społeczno-kulturowym, „która ma sprawić, że cele formalne stają się elementami wspólnie podzielanych wartości i norm zachowania”. ${ }^{6}$ Biorąc pod uwagę kryterium czasu, realizacja pierwszej możliwa jest szybciej, nie musi wymagać długiego czasu, ale z drugą jest inaczej, wymaga bowiem zmian behawioralnych i mentalnościowych. Przyjmuję, że wartości i cele określają perspektywę epistemologiczną, gdyż to właśnie dzięki nim możliwy jest opis przeszłości, sytuacji obecnej i przyszłości. „Aktorzy uwzględniają w swoich działaniach dominujący w społeczeństwie system wartości”?

\section{Rysunek 1. Instytucjonalizacja zmiany systemowej}

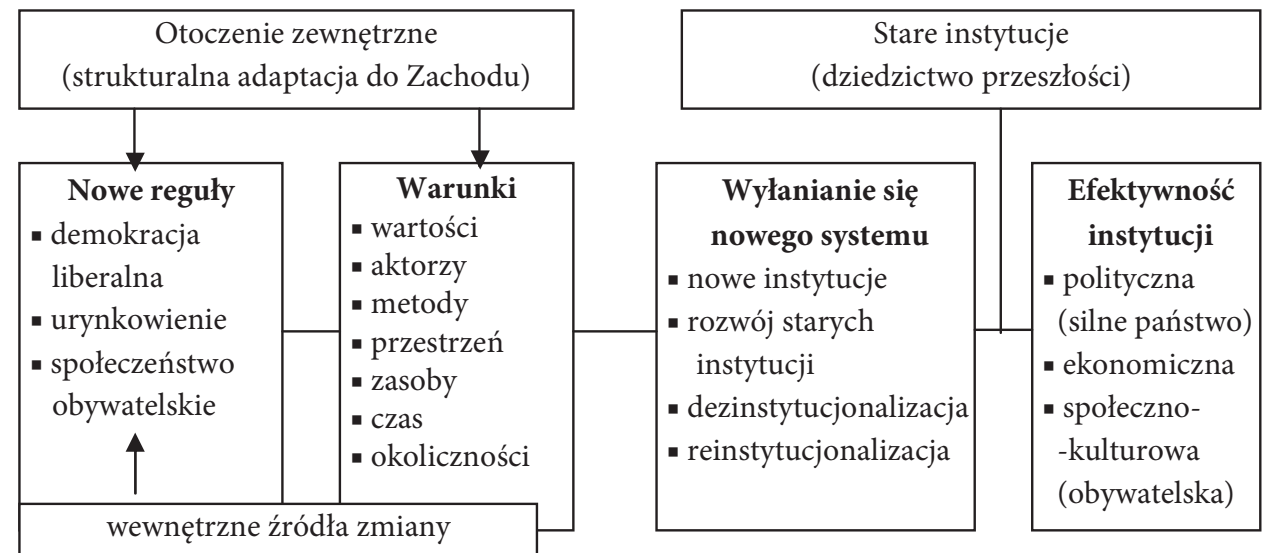

Źródło: W. Morawski, Zmiana instytucjonalna, PWN, Warszawa 1998, s. 22.

5 D.C. North, wykład wygłoszony w Wyższej Szkole Przedsiębiorczości i Zarządzania im. L. Koźmińskiego, Warszawa, 16 maja 2002 oraz D.C. North, The Contribution of the New Institutional Economics to an Understanding of the Transition Period, UNU Wider 1997.

6 W. Morawski, Socjologia ekonomiczna, PWN, Warszawa 2001, s. 59.

7 Ibidem, s. 15. 
Zgodnie z rysunkiem 1 o sposobie instytucjonalizacji zmiany decyduje siedem elementów: nowe reguły, wewnętrzne (polskie) źródła zmiany, strukturalna adaptacja do otoczenia zewnętrznego, różnorodność warunków realizacji, mechanizmy wyłaniania się nowych systemów (politycznego, ekonomicznego i społecznego), dziedzictwo przeszłości i skuteczność instytucjonalna. Nowe reguły obejmują instytucjonalizację w trzech wymiarach: politycznym (kształtowanie się liberalnej demokracji), rynkowym (budowa gospodarki rynkowo-prywatnej) i społeczno-kulturowym (tworzenie społeczeństwa obywatelskiego). Wewnętrzne źródła zmiany na poziomie systemu skupiają się na przyczynach upadku starego systemu. W odniesieniu do lobbingu źródłem zmian mogą być np. sami aktorzy (środowiska uprawiające rzecznictwo interesów), inicjujący podjęcie działań regulacyjnych te kwestie. Otoczenie zewnętrzne i adaptacja strukturalna pokazuje, w jakim stopniu zmiana stanowi rezultat przystosowania do świata zewnętrznego. W przypadku lobbingu przystąpienie do Unii Europejskiej narzuca konieczność dostosowania pewnych zachowań, np. ograniczenie korupcji, regulacji i ustawodawstwo. Warunki obejmują kilka czynników, takich jak: aktorzy metody, wartości, przestrzeń, zasoby, czas, okoliczności. Na forum krajowym aktorzy działają w przestrzeni publicznej, w której gospodarka wciąż jeszcze mocno zazębia się z polityką. Można rozróżnić metody działania: „imperatywne, związane z metodami odgórnymi” i prowadzące ku realizacji jakiegoś projektu oraz „oddolne, o charakterze interakcyjnym, gdy aktorzy aktywnie oddziałują na siebie". Zasoby, jakimi dysponują aktorzy, decydują o skuteczności ich aktywności. Pojęcie zasobów należy rozumieć w szerokim sensie, obejmuje ono wszelkie rodzaje kapitału: ekonomicznego, politycznego, społecznego. Ostatnim czynnikiem, szczególnie istotnym dla lobbingu, jest czas działań. „To, co dziś niemożliwe do zrealizowania, można zrealizować jutro, bo zmieniają się okoliczności: zły aktor okazuje się dobrym, złe metody nieaktualnymi, gdyż wypracowano nowe itp.." Wprowadzenie i zadomowienie się lobbingu rozumianego jako instytucji dzieje się w trakcie kilku rozgrywających się procesów: rozwoju instytucjonalnego (obejmującego instytucje formalne i nieformalne), dezinstytucjonalizacji, reinstytucjonalizacji, tworzenia nowych instytucji. Rozwój instytucjonalny polega na rozszerzaniu reguł, które istniały wcześniej. Można to odnieść do wzmocnienia roli Komisji Trójstronnej, czy zjawisk towarzyszących rzecznictwu interesów, takich jak klientelizm polityczny, klikowość, które czasami - błędnie - są utożsamiane $\mathrm{z}$ lobbingiem tout court. ${ }^{10}$ Dezinstytucjonalizacja obejmuje zanikanie pewnych reguł,

\footnotetext{
8 Ibidem.

9 Ibidem, s. 16.

10 O tego typu praktykach czy szerzej korupcjogennym wymiarze wzajemnych usług pisali J. Tarkowski czy J. Kurczewski. Por. Socjologia świata polityki, ISP PAN, Warszawa 1994.
} 
zarówno wewnątrz systemu, jak i systemu jako całości. W kontekście wyłaniającego się modelu lobbingu chodzi o zmianę statusu grup interesu, które przed rokiem 1989 korzystały z uprzywilejowanej pozycji (np. branże przemysłu ciężkiego, reprezentowane m.in. w Polskim Lobby Przemysłowym, czy chociażby siła związków zawodowych), a których rola i znaczenie obecnie słabnie. Reinstytucjonalizacja wprowadza nowe zasady działania. W kategoriach systemowych chodzi o pojawienie się reguł rynkowych w miejsce reguł gospodarki planowanej. Faza ta obejmuje również zmianę czy ustanowienie nowych ram prawnych. A zatem istotny jest cały zbudowany system regulacji umożliwiający prowadzenie lobbingu. Powstałe nowe ustawy (np. o zamówieniach publicznych, antykorupcyjne) przyczyniają się do ustalania nowych standardów działań, kształtowania „ducha praw”.

Stare instytucje (dziedzictwo przeszłości) spowolniają funkcjonowanie nowych. „Instytucje [...] traktuje się jako zmienne niezależne, bo działają samoczynnie (na wzór automatycznego pilota, ceremoniału, rytuału itp.). Działania aktorów są osadzone w sieci układów, które niełatwo dają się zmieniać, działania są »konstruowane " przez instytucje". ${ }^{11}$ Pod pojęciem starych instytucji kryją się również nieformalne, zgodnie z rozróżnieniem Northa, utrwalone zwyczaje, takie jak korumpowanie decydentów, układy klientalne, załatwianie spraw „po znajomości”. „Wieloletnie doświadczenie Polaków nauczyło ich, że wszędzie, gdzie stykają się ze światem instytucji, niezwykle ważną, jeśli nie kluczową rolę odgrywają »dojścia«, »chody«, "plecy«, »układy« czy bardziej elegancko - znajomości, poparcia, protekcje i koneksje [...]. Wszystkie te określenia mają jeden wspólny mianownik - dotyczą bezpośrednich, osobistych kontaktów, których celem jest uzyskanie przez strony jakichś korzyści, a w których przynajmniej jedna strona wykorzystuje w tym celu role formalne pełnione $\mathrm{w}$ różnych instytucjach. W związku z tym relacje te mają charakter relacji jawnie korupcyjnych bądź też lokują się w »szarej strefie«, tam gdzie przebiega wąska granica między legalnością a przestępstwem. [...] Długie lata życia w warunkach trwałych i powszechnych niedoborów i niesprawnych, nieprzyjaznych instytucji upowszechniły przekonanie, gruntowane codziennym doświadczeniem, że "układy« są najbardziej efektywnym, a niekiedy jedynym sposobem łagodzenia niedogodności i trudności życia codziennego". ${ }^{12}$

Skuteczność instytucji mierzona w trzech wymiarach: politycznym, ekonomicznym i społeczno-kulturowym oznacza kolejno: silne państwo, rozwiniętą i sprawną gospodarkę, społeczeństwo obywatelskie. Polska jest krajem o słabych tradycjach obywatelskich. Zgodnie z wynikami badań Putnama, poprzez zmianę

\footnotetext{
11 W. Morawski, Zmiana instytucjonalna, op.cit., s. 19.

12 J. Tarkowski, Socjologia świata polityki, t. 2, ISP PAN, Warszawa 1994, s. 19.
} 
instytucji formalnych można zmienić praktykę polityczną, wymaga to jednak czasu, a nawet zmiany generacyjnej. ${ }^{13}$ Budowie instytucji powinien towarzyszyć dziejący się równolegle proces ich zakorzeniania się, budowy społecznego kapitału, czyli zaufania ludzi do instytucji, wiary w ich moc i przekonania o ich efektywności. „Budowanie społecznego kapitału nie będzie łatwe, ale jest kluczem do sprawnej demokracji”. ${ }^{14}$ W Polsce ludzie przypisują wielką wagę powiązaniom i znajomościom, które „postrzegane są głównie jako mechanizmy reprodukcji nierówności, a więc jako mechanizmy, które nie są dostępne powszechnie i które działają przeciw zasadzie równości szans, opartej na nagrodach za jednostkowy wysiłek". ${ }^{15}$

\section{Demokracja a lobbing - uwarunkowania}

W dojrzałych demokracjach różnorodne grupy interesu stanowią nieodłączny element społeczeństwa obywatelskiego, aktywności i zaangażowania społeczno-politycznego obywateli. „W takim ujęciu są one traktowane jako integralny składnik społeczeństw pluralistycznych, gospodarki rynkowej i konkurencji, a lobby jest czymś w rodzaju pośrednika między obywatelem a władzą. ${ }^{16}$

Takie podejście badawcze w odniesieniu do tego zjawiska reprezentowali politologowie, socjologowie (Lembruch, Greenwood, van Schendelen). W Polsce jednym z pierwszych, który wspominał o lobbingu, był Stanisław Erlich.

Wzrost zainteresowania lobbingiem i rzecznictwem interesów widoczny jest od lat dziewięćdziesiątych ubiegłego wieku. Miało na to wpływ wiele zjawisk związanych z procesami politycznymi, ekonomicznymi i gospodarczymi. Do takich należy zaliczyć przede wszystkim globalizację, ${ }^{17}$ procesy umiędzynaradawiania gospodarek, a także szereg zjawisk politycznych: koniec zimnej wojny, przemiany demokratyczne,

13 „[...] Historia instytucji w przeważającej części toczy się powoli. Gdzie w grę wchodzi budowanie instytucji (a nie jedynie pisanie konstytucji), czas należy mierzyć dziesiątkami lat. Tak było w przypadku landów niemieckich, i tak jest w przypadku włoskich regionów, a przed nimi komunalnych republik, i tak będzie w przypadku ekskomunistycznych państw euroazjatyckich, nawet jeśli wydarzenia przebiegać będą według najbardziej optymistycznego scenariusza”. R. Putnam, Demokracja w działaniu. Tradycje obywatelskie we współczesnych Włoszech, Znak, Kraków 1995, s. 286.

14 Ibidem, s. 289

15 P. Morawski, Rola znajomości i powiązań $w$ dyskursie szans życiowych $w$ Polsce $i$ Stanach Zjednoczonych, w: Oswajanie rzeczywistości. Między realnym socjalizmem a realną demokracją, red. M. Marody, Instytut Studiów Społecznych UW, Warszawa 1996, s. 86.

16 K. Jasiecki, Lobbing gospodarczy w Polsce, „Studia Socjologiczne” 2000 nr 4.

17 Zachęcam tutaj do posłużenia się rozumieniem globalizacji zaproponowanym przez A. Giddensa i poszerzonym przez E. Wnuka-Lipińskiego w pracy Świat międzyepoki. Globalizacja, demokracja, państwo narodowe, Znak, ISP PAN, Kraków 2006. 
wzrost korupcji. ${ }^{18}$ Wymienione zjawiska budują kontekst dla globalnych działań lobbingowych. Lobbing i rzecznictwo interesów zaczyna być aktywnością praktykowaną przez globalnych aktorów. Wymusza to także konieczność wprowadzenia regulacji prawnych w tym zakresie oraz zmian w już istniejących. Spowodowały one, że rzecznictwo interesów poddało się procesowi umiędzynarodowienia. By działania podejmowane na forum krajowym mogły być skuteczne, należy w nich uwzględniać wymiar europejski (np. lobbing gospodarczy, polityczny) czy globalny (np. lobbing Polski do NATO czy starania Wrocławia o Expo 2012). ${ }^{19}$

\subsection{Różnorodność demokracji a aktywność lobbingowa}

Pisząc o demokracji, właściwie powinniśmy to robić w liczbie mnogiej, gdyż nie ma jednej demokracji. Zazwyczaj pojęcie to doprecyzujemy, dodając jakiś przymiotnik: demokracja przedstawicielska, deliberacyjna, partycypacyjna, bezpośrednia, medialna itp. Wymienione określenia pokazują, że coraz bardziej demokracja wymaga zaangażowania obywatelskiego, które może przybierać różne formy: od udziału w wyborach, referendach aż po zaangażowanie w mechanizmy i procedury konsultacji. Demokracja nie funkcjonuje w próżni, jest powiązana z globalizacją. Jak to trafnie podsumował amerykański socjolog B. Barber, „To demokracja powinna wspierać i zmieniać globalizację, a nie na odwrót. Kiedy globalizacją rządzi wyłącznie gospodarka rynkowa, zaczyna w niej dominować najsilniejsza kultura. Ironia polega na tym, że rynek, który powinien chronić wolność wyboru, w rzeczywistości wspiera monopol. Z kolei demokratyczne państwo, wspierając rynek, chroni monopol, zamiast wspierać pluralizm w kulturze. Esencją demokracji nie jest jedynie wolność, lecz właśnie pluralizm, poznanie, ale i ochrona różnic kulturowych. W tym sensie demokracja powinna oznaczać większą ochronę pluralizmu w kulturze". ${ }^{20}$

Lobbing funkcjonuje w kontekście demokratycznym i w takim kontekście był zazwyczaj badany. ${ }^{21}$ Mamy różne modele demokracji. Według F. Descheemaekere’a ${ }^{22}$ w tradycji Rouseau lobbing postrzegany jest jako ekspresja partykularnych interesów.

18 Por. K. Jasiecki, ekspertyza na zlecenie Klubu Parlamentarnego Unii Wolności, Warszawa 1999, maszynopis.

19 Ibidem.

20 B. Barber, Kultura dziecinnieje, „Dziennik” 20.12.2006, za: Dziennik.pl

21 Por. K. Jasiecki, M. Molęda-Zdziech, U. Kurczewska, Lobbing. Sztuka skutecznego wywierania wpływu, OE, Kraków 2006, s. 53-74; R. van Schendelen, Machiavelli w Brukseli. Sztuka lobbingu w Unii Europejskiej, GWP, Gdańsk 2006, s. 281-317.

22 F. Deschmeemaekere, Le cyber lobbying, Lavoisier, Paris 2007, s. 25. 
Ten sposób percepcji dominuje m.in. we Francji, ale i w Polsce. ${ }^{23} \mathrm{Z}$ drugiej strony mamy tradycję A. de Tocqueville’a podkreślania roli społeczeństwa obywatelskiego, jego relacji z państwem, ważne są zatem interesy poszczególnych grup, bo w rezultacie to one tworzą interes ogólny. To spojrzenie na lobbing przeważa w Stanach Zjednoczonych.

Kenneth E. Boulding (1970) wyróżnił cztery rodzaje demokracji, w zależności od stopnia wpływu rządu, roli świata gospodarczego i społeczeństwa obywatelskiego. Są to:

1) demokracja republikańska, w której ideałem jest obrona interesu ogólnego narodu;

2) demokracja złożona, w której ideał republikański nie przeszkadza w ekspresji różnorodnych grup interesu;

3) demokracja elitystyczna lub przedstawicielska, w której nie wszyscy mogą uczestniczyć w wykonywaniu władzy;

4) demokracja liberalna, pluralistyczna, która stanowi ramy najbardziej przyjazne dla lobbingu (poprzez system checks and balances - procedury kontroli i równoważenia wpływów) na poziomie społeczno-politycznym.

\section{Modele lobbingu i ich ewolucja}

Do tej pory w literaturze przedmiotu funkcjonowały trzy modele lobbingu: pluralistyczny, typowy dla Stanów Zjednoczonych i Wielkiej Brytanii, neokorporatywistyczny, charakterystyczny dla krajów Europy Zachodniej, oraz model mieszany - cechujący Unię Europejską. Modele te zostały wyróżnione na podstawie wielu kryteriów i w sposób syntetyczny przedstawione w tabeli 1 .

Wraz z rewolucją informacyjną, wyłanianiem się nowej formy gospodarki opartej na wiedzy i informacjach przedstawione powyżej modele zaczynają ewoluować.

Po pierwsze, wraz z globalizacją, tworzeniem sieci, procesami integracyjnymi, zmieniają się ramy polityczno-gospodarcze, w jakich funkcjonujemy. Zasada przejrzystości staje się naczelną zasadą administracji krajowych, europejskich czy międzynarodowych organizacji.

Po drugie, zmieniają się kluczowi aktorzy lobbingowi. Klasyczni aktorzy lobbingowi, do których zaliczamy przede wszystkim: duże grupy przemysłowe, federacje zawodowe i związki pracodawców, organizacje międzynarodowe, przedstawicielstwa

23 Por. Opinia społeczna o korupcji i lobbingu w Polsce, CBOS, Warszawa, maj 2010, BS/63/2010, http://www.cbos. pl/SPISKOM.POL/2010/K_063_10.PDF (dostęp 09.07.2011). 
regionów, NGO's, think tanks, konsultantów i adwokatów, media narodowe, zaczynają być wypierani przez nowych aktorów lobbingowych. Do tej kategorii zalicza się rosnący liczebnie i znaczeniowo sektor MSP, organizacje pracodawców oraz pracobiorców na poziomie lokalnym, stowarzyszenia (przede wszystkim organizacje typu strażniczego tzw. watch dog), grupy interesu lokalnego, stowarzyszenia rodziców, użytkowników, zwykłych obywateli; liderów opinii, lokalne autorytety, agencje PR i media lokalne.

Tabela 1. Modele lobbingu w USA, Europie Zachodniej i Unii Europejskiej

\begin{tabular}{|c|c|c|c|}
\hline $\begin{array}{l}\text { Kluczowe } \\
\text { wyróżniki }\end{array}$ & $\begin{array}{c}\text { USA } \\
\text { (model pluralistyczny) }\end{array}$ & $\begin{array}{l}\text { Państwa Europy Zachodniej } \\
\text { (model neokorporatywistyczny) }\end{array}$ & Instytucje Unii Europejskiej \\
\hline $\begin{array}{l}\text { Filozofia } \\
\text { polityczna }\end{array}$ & $\begin{array}{l}\text { teorie grup nacisku } \\
\text { i pluralizmu elit }\end{array}$ & $\begin{array}{l}\text { reprezentacje partykularnych } \\
\text { interesów }\end{array}$ & $\begin{array}{l}\text { pozatraktatowy partner w procesie } \\
\text { podejmowania decyzji w UE, element } \\
\text { dialogu społecznego i obywatelskiego }\end{array}$ \\
\hline $\begin{array}{l}\text { Przesłanki } \\
\text { historyczne } \\
\text { i ustrojowe }\end{array}$ & $\begin{array}{l}\text { brak feudalnych ograni- } \\
\text { czeń w rozwoju demo- } \\
\text { kracji, duża aktywność } \\
\text { obywatelska }\end{array}$ & $\begin{array}{l}\text { tradycje reprezentacji stanowych } \\
\text { oraz sformalizowanych organiza- } \\
\text { cji grup społeczno-zawodowych, } \\
\text { korporacjonizm }\end{array}$ & $\begin{array}{l}\text { zwiększanie roli decyzyjnej ponadnaro- } \\
\text { dowych instytucji EWG/WE/UE, tworze- } \\
\text { nie reprezentacji różnych dziedzin życia } \\
\text { gospodarczego i społecznego }\end{array}$ \\
\hline $\begin{array}{l}\text { System } \\
\text { rządów }\end{array}$ & $\begin{array}{l}\text { prezydencki, silna pozycja } \\
\text { władzy ustawodawczej }\end{array}$ & $\begin{array}{l}\text { przewaga systemów } \\
\text { parlamentarno-gabinetowych }\end{array}$ & $\begin{array}{l}\text { skomplikowane relacje pomiędzy Radą, } \\
\text { Komisją i Parlamentem Europejskim }\end{array}$ \\
\hline $\begin{array}{l}\text { System } \\
\text { partyjny }\end{array}$ & $\begin{array}{l}\text { utrwalony system } \\
\text { dwupartyjny }\end{array}$ & $\begin{array}{l}\text { dominacja systemów } \\
\text { wielopartyjnych }\end{array}$ & $\begin{array}{l}\text { grupy polityczne w Parlamencie } \\
\text { Europejskim }\end{array}$ \\
\hline Status & $\begin{array}{l}\text { regulacja ustawowa, } \\
\text { mocna instytucjonalizacjai } \\
\text { profesjonalizacja }\end{array}$ & $\begin{array}{l}\text { brak regulacji lub ich zalążkowy } \\
\text { charakter }\end{array}$ & $\begin{array}{l}\text { regulacje w Parlamencie Europejskim } \\
\text { i Komisji Europejskiej, postępująca } \\
\text { instytucjonalizacja; samoregulacje } \\
\text { środowiskowe (kodeksy etyczne stowa- } \\
\text { rzyszeń lobbingowych) }\end{array}$ \\
\hline $\begin{array}{l}\text { Kultura } \\
\text { polityczna }\end{array}$ & duże znaczenie prawa & różnice krajowe i regionalne & $\begin{array}{l}\text { technokratyczne procedury } \\
\text { konsultacyjne }\end{array}$ \\
\hline $\begin{array}{l}\text { Percepcja } \\
\text { społeczna }\end{array}$ & $\begin{array}{l}\text { stały i ważny element } \\
\text { procesu decyzyjnego, } \\
\text { szeroki oddźwięk }\end{array}$ & $\begin{array}{l}\text { ambiwalencja, krytyka } \\
\text { i podejrzliwość, niejawny } \\
\text { charakter }\end{array}$ & $\begin{array}{l}\text { zjawisko powszechnie znane, stopniowa } \\
\text { akceptacja }\end{array}$ \\
\hline Terminologia & $\begin{array}{l}\text { lobbying, lobbying } \\
\text { industry, lobbies, } \\
\text { advocacy }\end{array}$ & $\begin{array}{l}\text { grupy nacisku, grupy interesu, } \\
\text { związki interesów }\end{array}$ & $\begin{array}{l}\text { otwarty i strukturalny dialog ze spe- } \\
\text { cjalnymi grupami interesu, rozróżnie- } \\
\text { nie krajowych i międzynarodowych grup } \\
\text { nacisku }\end{array}$ \\
\hline
\end{tabular}

Źródło: M. Molęda-Zdziech, Modele lobbingu, w: K. Jasiecki, M. Molęda-Zdziech, U. Kurczewska, Lobbing. Sztuka skutecznego wywierania wpływu, OE, Kraków 2000 oraz K. Jasiecki, Lobbing w USA, Europie Zachodniej i Polsce. Podobieństwa i różnice, „Studia Europejskie Centrum Europejskiego UW” 2002 nr 4 (24), s. 117-134.

Po trzecie, zmienia się arsenał metod i technik lobbingowych, do którego owi aktorzy sięgają. Metody tradycyjne, oparte na kontaktach twarzą w twarz, zaczynają być wypierane przez lobbing oddolny, oparty na liczebności grupy, a także na działaniach on-line, nazwanych cyberlobbingiem. Według Bruno Gosselina, autora pierwszego słownika lobbingu, „E-lobbing lub cyberlobbing polega na dostosowaniu strategii wywierania wpływu do nowych technologii informacyjno-komunikacyjnych. 
Koncentruje się na wykorzystaniu Internetu, we wszystkich jego formach, jako kanale rozpowszechniania (dystrybucji)"”. ${ }^{44}$ F. Descheemaekere, profesor zarządzania z Groupe Ecole Superiéure de Commerce et de Management ESCEM Tour-Poitiers, autor pierwszej książki poświęconej cyberlobbingowi, uzupełnia tę definicję o element odbiorcy lobbingowych działań - władze publiczne. „Cyberlobbing lub e-lobbing (czasami mówi się o lobbingu on-line) jest wdrożeniem nowych technologii komunikacyjnych i informacyjnych i ich zastosowaniem w ramach kampanii działań mających na celu wywarcie wpływu na decydenta publicznego". ${ }^{25}$

Po czwarte, dorosło już pokolenie, które wychowywało się w erze internetu, internet jest dla tego pokolenia naturalnym środowiskiem do działania, życia. To pokolenie doprowadziło do stworzenia wikinomii, nowej formy gospodarki, wykorzystującej informacje i wiedzę.

\section{Wikinomia jako forma gospodarki opartej na informacjach i wiedzy}

Gospodarka oparta na wiedzy (knowledge-based economy) zgodnie z definicją OECD „to gospodarka oparta wprost na tworzeniu, traktowanym jako produkcja, oraz dalszym przekazywaniu, czyli dystrybucji oraz praktycznym wykorzystaniu wiedzy i informacji. Są więc trzy etapy będące podstawą rozwoju gospodarczego produkcja, dystrybucja, wdrożenie. Wiedza jest określonym produktem (niezależnym bytem), który napędza rozwój”. ${ }^{26}$

Na poziomie Unii Europejskiej wiodące znaczenie tej formie gospodarki zostało przypisane w strategii lizbońskiej. Bliskoznacznymi terminami na określenie tej formy gospodarki są: nowa gospodarka (new economy), gospodarka cyfrowa (digital economy), gospodarka sieciowa (network economy), które nawiązują do pojęcia społeczeństwa informacyjnego z początku lat siedemdziesiątych XX wieku. Miało ono wiele wspólnego $\mathrm{z}$ teorią trzech fal technologicznych, zaproponowaną przez amerykańskiego socjologa i futurologa, Alvina Tofflera.

Trzecia fala to synergia możliwości technologicznych, komunikacyjnych i intelektu ludzkiego. Wykorzystuje nieznane dotąd możliwości komunikacji w ramach globalizującego się świata i umiędzynarodawiających się gospodarek. Nie jest to

\footnotetext{
24 Za: B. Gosselin, Le dictionnaire du lobbying, EMS Collombelles Editions 2003, s. 61.

25 F. Descheemaekere, Le cyber lobbying, op.cit., s. 13.

26 The Knowledge-Based Economy, OECD, Paris 1996, s. 7 oraz http://pl.wikipedia.org/wiki/Gospodarka_oparta_ na_wiedzy.(dostęp 15.10.2010).
} 
faza jednorodna. Niemniej jednak rewolucja informacyjna stała się faktem. Według danych Internet World Stats z końca 2009 roku liczba internautów na całym świecie wynosiła blisko $2 \mathrm{mld}$, a w Polsce - ponad $20 \mathrm{mln}$ (52\% populacji). Ponadto aż 90\% wszystkich mieszkańców Islandii i Norwegii korzystało z internetu, co czyni te kraje najbardziej zinformatyzowanymi na świecie. ${ }^{27}$

Tabela 2. Trzy fale rozwoju według A. Tofflera

\begin{tabular}{|l|l|l|}
\hline \multicolumn{1}{|c|}{ Nazwa fali } & \multicolumn{1}{|c|}{ Cezura, kluczowy wynalazek } & \multicolumn{1}{c|}{ Opis } \\
\hline Pierwsza fala - agrarna & $\begin{array}{l}\text { około } 10 \text { tys. lat temu, wynalazek koła } \\
\text { i innych związanych z uprawą roli }\end{array}$ & $\begin{array}{l}\text { rolnictwo, zmiana trybu życia } \\
\text { z nomadycznego na osiadły }\end{array}$ \\
\hline Druga fala - przemysłowa & wynalazek druku i maszyny parowej & $\begin{array}{l}\text { wysoka produkcja stali, energii elektrycznej, } \\
\text { rozwój przemysłu wydobywczego; } \\
\text { wprowadzenie masowego transportu; zasad } \\
\text { standaryzacji i uniformizacji }\end{array}$ \\
\hline $\begin{array}{l}\text { Trzecia fala } \\
\text { - poprzemysłowa }\end{array}$ & $\begin{array}{l}\text { współczesna, technologie } \\
\text { informacyjno-komunikacyjne } \\
\text { (Information and Communication } \\
\text { Technologies - ICT) }\end{array}$ & $\begin{array}{l}\text { wdrażanie na masową skalę technologii } \\
\text { informacyjnych i komunikacyjnych; } \\
\text { przełamanie bariery czasu i przestrzeni }\end{array}$ \\
\hline
\end{tabular}

Źródło: opracowanie własne na podstawie: A. Toffler, Trzecia fala, PIW, Warszawa 1997.

Upowszechnienie i udomowienie internetu i nowych mediów spowodowało powstanie nowej formy ekonomii - wikinomię. Termin ten pochodzi od hawajskiego „Wiki”, co znaczy tyle, co szybko, i został wyłoniony w drodze konkursu na tytuł książki przygotowanej przez Dona Tapscotta i Anthony’ego D. Williamsona - Wikinomia. O globalnej wspótpracy, która zmienia wszystko, opublikowanej w 2006 roku. ${ }^{28}$ Jak pisze profesor Jung, książka ta ,jest pierwszą akademicką próbą zbudowania zrębów teorii ekonomicznej wokół względnie nowego (na masową skalę występującego od 2005 roku) zjawiska, jakim jest Web 2.0". ${ }^{29}$

Czym różni się zatem Web 2.0 od swego poprzednika Web 1.0? Chodzi przede wszystkim o aktywność i stopień zaangażowanie ich użytkowników. „Różnica między Web 1.0 a 2.0 jest taka jak między pasywnym a aktywnym korzystaniem z mediów, między konsumpcją a twórczością (kreacją). W dodatku do tej aktywnej kreacji niepotrzebne jest drogie oprogramowanie i pogłębiona wiedza, lecz darmowe i łatwe w użyciu aplikacje powszechnie dostępne w sieci”. ${ }^{30}$

\footnotetext{
27 http://www.internetworldstats.com/

28 Polskie wydanie ukazało się dwa lata później. D. Tapscott, A.D. Williamson, Wikinomia. O globalnej współpracy, która zmieniła wszystko, WAIP, Warszawa 2008.

29 Wokót mediów ery Web 2.0, red. B. Jung, WAiP, Warszawa 2010.

30 Ibidem, s. 7.
} 
Web 2.0 pociąga za sobą różnego typu różnorodne konsekwencje: ekonomiczne, społeczno-kulturowe i polityczne. Jeśli chodzi o gospodarkę, to mamy do czynienia z gospodarką cyfrową. ${ }^{31}$ Skutki społeczno-kulturowe to np. pojawienie się klasy kreatywnej, ${ }^{32}$ ale także (a może przede wszystkim) wykorzystanie zaufania społecznego i wprowadzanie metod Wiki, czyli rozwiązywania problemów przez współpracę w sieci (por. tabela 3). Florida - na podstawie danych dla Międzynarodowej Organizacji Pracy (ILO) z 45 krajów - szacuje jej liczebność na 100-150 mln, z tego 20-30\% to mieszkańcy Stanów Zjednoczonych.

Tabela 3. Podziały klasy kreatywnej - charakterystyka

\begin{tabular}{|l|l|}
\hline \multicolumn{1}{|c|}{ Kategoria klasy } & \multicolumn{1}{c|}{ Opis } \\
\hline Klasa superkreatywna & $\begin{array}{l}\text { naukowcy, inżynierowie, profesorowie, poeci, pisarze, artyści, aktorzy, piosenkarze i show } \\
\text { biznes, think tanks; najwyższy stopień kreatywności, narzucanie mód i trendów; } \\
\text { w USA to 10,6\% ogółu zatrudnionych }\end{array}$ \\
\hline $\begin{array}{l}\text { Kreatywni } \\
\text { profesjonaliści }\end{array}$ & $\begin{array}{l}\text { pracownicy branży high tech, przemysłów nasyconych wiedzą, usług finansowych, praw- } \\
\text { nych, medycznych, zarządzanie biznesem, konsulting; } \\
\text { praca polega na kreatywnym rozwiązywaniu problemów; wymagane wysokie i dobre } \\
\text { wykształcenie i kapitał społeczny (sieci kontaktów); wysokie zarobki i prestiż społeczny; } \\
\text { w USA to 18,2\% ogółu zatrudnionych }\end{array}$ \\
\hline Klasa usługowa & $\begin{array}{l}\text { pracownicy sektora usług; praca o niskim stopniu niezależności(procedury i rutyna); praca } \\
\text { nisko opłacana; niski prestiż społeczny; } \\
\text { w USA to około 44\% ogółu zatrudnionych }\end{array}$ \\
\hline $\begin{array}{l}\text { Klasa pracująca } \\
\text { i rolnicy }\end{array}$ & $\begin{array}{l}\text { robotnicy przemysłowi, rolnicy; } \\
\text { w USA klasa pracująca to 24,5\%, a rolnicy zaledwie 2,6\% ogółu zatrudnionych }\end{array}$ \\
\hline
\end{tabular}

Źródło: R. Florida, Narodziny klasy kreatywnej, Narodowe Centrum Kultury, Warszawa 2010.

Dotyczy to m.in. zmiany modeli biznesowych: „Ten nowy model ekonomiczny już od dawna funkcjonuje w branży programistycznej, farmaceutycznej, a także w innych innowacyjnych gałęziach przemysłu. Obecnie zaczyna on obejmować całość gospodarki światowej. [...] Wiele $\mathrm{z}$ tych historii wiąże się z niesłychanie szybkim rozwojem takich zjawisk, jak Myspace, InnoCentive, Flickr, Second Life, You Tube oraz Human Genome Project (projekt poznania ludzkiego genomu)".

Tabela 4. Charakterystyka zasad funkcjonowania Wikinomii

\begin{tabular}{|l|l|}
\hline \multicolumn{1}{|c|}{ Zasady } & \multicolumn{1}{c|}{ Opis } \\
\hline Otwartość w dzieleniu się informacjami & $\begin{array}{l}\text { otwartość wynika z przeświadczenia, że inni użytkownicy odwzajemnią mi } \\
\text { się tym samym }\end{array}$ \\
\hline $\begin{array}{l}\text { Peering, czyli współpraca na równych } \\
\text { zasadach }\end{array}$ & $\begin{array}{l}\text { system komunikacji na zasadzie „jak równy z równym”, technika dzielenia } \\
\text { się, przesyłania plików muzycznych, tekstowych przez internet }\end{array}$ \\
\hline
\end{tabular}

\footnotetext{
31 Źródłem ponad połowy wartości eksportu USA były prawa autorskie, patenty i obrót nimi.

32 R. Florida, Narodziny klasy kreatywnej, Narodowe Centrum Kultury, Warszawa 2011.
} 


\begin{tabular}{|l|l|}
\hline Prosumeryzm & $\begin{array}{l}\text { Do-lt-Yourself (D.I.Y) - zrób to sam! jako naczelne hasło tej działalności; } \\
\text { każdy użytkownik może być również producentem }\end{array}$ \\
\hline Globalne współdziałanie & $\begin{array}{l}\text { wynika z wiary w mądrość innych; zawsze więcej mądrych } \\
\text { i kreatywnych (w kategoriach liczebności) jest poza firmą } \\
\text { niż w niej samej }\end{array}$ \\
\hline
\end{tabular}

Źródło: opracowanie własne na podstawie: D. Tapscott, A.D. Williamson, Wikinomia. O globalnej wspótpracy, która zmieniła wszystko, WAiP, Warszawa 2008.

Takie zasady współpracy dotyczą również pozarządowych organizacji międzynarodowych, dysponujących swoimi filiami w różnych krajach. Filozofia dzielenia się swoim wypracowanym know how stanowi zasadę tych organizacji (np. Amnesty International, Greenpeace, WWF).

\subsection{Wikinomia a cyberlobbing}

Nowe zasady przedstawione powyżej nie pozostają bez wpływu na działalność lobbingową, zarówno w wykonaniu aktorów gospodarczych, jak i sektora organizacji pozarządowych. Zmiany technologiczne wpływają na zmiany społeczne, ekonomiczne i polityczne. Początkowo komunikacja w internecie sprowadzała się przede wszystkim do wysyłania poczty elektronicznej oraz uczestniczenia w grupach dyskusyjnych. Z czasem pojawiły się różnego rodzaju fora, komunikatory i blogi. Obecnie jedną z najszybciej rozwijających się form korzystania z internetu jest tworzenie wirtualnych społeczności, które cechują się tym, że zawierają w sobie wszystkie wcześniejsze formy komunikacji sieciowej. Społeczności te zorientowane są zarówno na organizację czasu wolnego, pozostawanie w kontakcie ze znajomymi ze świata rzeczywistego, jak i nawiązywanie nowych znajomości - towarzyskich i biznesowych. Ze względu na funkcje, które mają spełniać, ukierunkowane są na różnorodne grupy docelowe. Powyższe przemiany nie pozostają bez wpływu na aktywność aktorów społecznych, stwarzając łatwiejsze możliwości różnych form aktywizmu, w tym lobbingu i rzecznictwa interesów, który przybiera formę cyberlobbingu.

\subsubsection{Kontekst umożliwiający pojawienie się cyberlobbingu}

Profesor F.B. Huyghes, francuski politolog, celnie zauważa, że współcześnie „nasze społeczeństwa zdają się przechodzić od demokracji autorytetu do demokracji wpływu" ${ }^{33}$ Jego zdaniem na zjawisko to wskazuje wiele czynników. Między innymi to, co zwykło się nazywać „kryzysem polityki”. Mamy do czynienia z załamaniem się różnych ideologii, które manifestuje się poprzez dyskredytację wystąpień

33 F.B. Huyghes, Démocratie d'autorité, démocratie d'influence. En quoi consistent les nouveaux pouvoirs?, http://www.huyghe.fr/actu_322.htm 
doktrynalnych. Wydaje się temu sprzyjać perspektywa postmodernistyczna, która podkreśla osłabianie lub przynajmniej destabilizację wielkich metanarracji historii, wyrażających (lub pretendujących do tego) ogólne prawdy dotyczące „conditio humana" (idee Postępu, Rozumu, Wolności, Walki, Klasy), ${ }^{34}$ proponując w zamian mikronarracje. Radykalni postmoderniści kładli nacisk na niestabilny status rzeczywistości społecznej. „Stąd też życie społeczne i polityczne jest obecnie odgrywane w rzeczywistości intensywnej symulacji, w której wymiana symboliczna nie odnosi się już dłużej do rzeczywistości obiektywnej, zewnętrznej, do tego, co podlega wymianie - świat skopiowanych kopii bez żadnych oryginalnych odniesień, gdzie język już dłużej nie naśladuje rzeczywistości, ale raczej zaznacza jej zupełną nieobecność jako kategorię znaczącą". ${ }^{35}$ Chodzi o Baudrillardowską ideę hiperrzeczywistości, „świata dyskursu”, który znajduje się poza rzeczywistością. ${ }^{36} \mathrm{~W}$ tej perspektywie tożsamości są kategorią dynamiczną, konstruowaną poprzez dyskurs. „Tożsamości ludzkie są zatem podatne na zakwestionowanie, zależne od kontekstu, wielorakie, fragmentaryczne i chwilowe - ludzie konstruują wiele wariantów samych siebie, które pojawiają się czasem w niespójnych i sprzecznych zestawieniach, zależnych od kontekstów, które same często na siebie nachodzą lub są pozornie niewymierne". ${ }^{37}$ Zmienność tożsamości, ich wielość jest charakterystyczna dla czasów Baumanowskiej „płynnej nowoczesności” ${ }^{38}$ czy „czasu plemion” - przygodnych lub trwałych grup, nowych plemion według Maffesolego ${ }^{39}$

Ponadto ciągłe odwoływanie się do złożoności wyzwań lub zagrożeń wynikających z globalizacji (w aspekcie ekonomicznym, politycznym, kulturowym i zglobalizowanej przestępczości). ${ }^{40}$ „[...] Charakter współczesnej gospodarki, uzależnionej przede wszystkim od tworzenia i przekazywania informacji, sprawił, że granice państwowe stały się nieistotne, co znajduje swoje odzwierciedlenie w strukturze prawnej i instytucjonalnej". 41

Równolegle z zasygnalizowanymi procesami obserwujemy wyłanianie się nowych aktorów lobbingowych: organizacji strażniczych, ruchów protestacyjnych reprezentujących społeczeństwo obywatelskie, jak i organizacji pozarządowych tzw. NGO'sów. ${ }^{42}$ Liczbę organizacji pozarządowych o charakterze międzynarodowym

\footnotetext{
34 D. Barney, Społeczeństwo sieci, Wydawnictwo Sic!, Warszawa 2008, s. 27.

35 J. Baudrillard, Simulations, Semiotext (e), New York 1983, za: ibidem, s. 28.

36 Ibidem.

37 Ibidem.

38 Z. Bauman, Płynna nowoczesność, Wydawnictwo Literackie, Kraków 2006.

39 M. Maffesoli, Czas plemion. Schyłek indywidualizmu w społeczeństwach ponowoczesnych, PWN, Warszawa 2008.

40 Odwołuję się do rozróżnienia zaproponowanego przez E. Wnuka-Lipińskiego w: Świat międzyepoki, op.cit.

41 D. Robertson, Słownik polityki, Wydawnictwo Sic!, Warszawa 2009, hasło: globalizacja, s. 129.

42 Sektor organizacji pozarządowych w syntetyczny sposób został zaprezentowany przez P. Ryfman, Les ONG, La découverte, Paris 2004.
} 
na świecie szacuje się na około 25 tys., podczas gdy na początku XX wieku było ich zaledwie kilka. ${ }^{43}$ Są to „współczesne formy samoorganizacji społecznej, struktury integrujące grupy obywateli, które cechuje względnie dojrzała tożsamość społeczna, określony stopień zorganizowania, prywatny charakter inicjatywy, dobrowolność uczestnictwa, niezależność i niekomercyjność, a także na ogół znaczny udział wolontariatu i istotna rola w kształtowaniu postaw ludzkich (zarówno osób uczestniczących w organizacjach, jak i mających jakikolwiek z nimi kontakt)”."44

Ważnym, dodatkowym kryterium charakteryzującym organizacje pozarządowe jest określony obszar działania - sfera publiczna lub sfera polityki nieinstytucjonalnej. ${ }^{45}$ Wystarczy przywołać wzrastający na znaczeniu ruch konsumencki czy alterglobalizacyjny (gigantyczne manifestacje w Seattle i Porto Allegre) ${ }^{46}$ Posługują się one sprawnie bojkotami, organizują manifestacje, blokady, często przeciwko już przegłosowanym prawom. Potrafią dotrzeć do mediów i nawiązać z nimi długofalową współpracę. Wzrasta liczba organizacji pozarządowych NGO i stowarzyszeń, reprezentujących społeczeństwo obywatelskie. ${ }^{47}$ Zazwyczaj odwołują się one do wartości uniwersalnych (kwestie związane z ekologią, prawami człowieka), specjalizując się w jakiejś jednej wybranej sprawie. Ich strategia działania polega na antycypacji kwestii problemowych i przygotowywaniu własnych propozycji rozwiązań. Stanowiska tych organizacji zazwyczaj podważają oficjalne stanowiska rządu, są krytyczne wobec działań korporacji. Stanowią inspirację dla tworzonych kart etycznych, norm technicznych, ekologicznych i społecznych, tego, co nazywamy soft law. Sektor NGO's równie sprawnie prowadzi działania typu media relations, angażuje się często w ujawnianie skandali i różnych nieprawidłowości. ${ }^{48}$ Równolegle lobbies starają się uzyskać korzystne dla siebie decyzje poprzez wywieranie wpływu na władze publiczne.

Lobbing nie ogranicza się jedynie do „strategii kija i marchewki”, ${ }^{49}$ ani jedynie do strategii komunikacyjnych. Skuteczni lobbyści potrafią argumentować i wpływać na

43 D. Robertson, Stownik polityki, op.cit., s. 129

44 Encyklopedia socjologii, Oficyna Naukowa, Warszawa 2005, suplement, hasło: organizacje pozarządowe, s. $170-178$.

$45 \mathrm{~W}$ polskiej literaturze badacze posługują się również takimi określeniami, jak: organizacje społeczne (Z. Woźniak), organizacje obywatelskie (A. Siciński).

46 Przykładem organizacji reprezentującej alterglobalistów może być ruch Attac, o którym pisałam w: Nic o nas bez nas (o organizacji antyglobalistycznej Attac), „Decydent. Pismo Lobbingowe” 07.08.2002, s. 16-17.

47 W Polsce na I kwartał 2008 roku w rejestrze REGON zarejestrowanych było: 8237 stowarzyszeń, 9106 fundacji, za: http://civicpedia.ngo.pl/ngo/362510.html\#, pod linkiem dostępna jest szczegółowa aktualna charakterystyka sektora. Zainteresowanych rolą NGO’s w procesie globalizacji odsyłam do pracy : Les ONG acteurs de la mondialisation, „Problèmes politiques et sociaux” n 918, Documentation française, Paris, août 2002.

48 Liczne przykłady takich działań zostały przedstawione w książce: J. Stauber, S. Rampton, L’industrie du mensonge: lobbying, communication, publicité et médias, Agone, Paris 2004.

49 Czyli grożenia strajkiem, powiadamiania organów sprawiedliwości, grożenia mediami lub obietnic nagród finansowych, ułatwień różnego typu itp. 
podejmowane kroki dostarczając rozwiązań, sugestii, ułatwień, dokumentacji, tak aby popchnąć decydenta w oczekiwanym kierunku. Ta praca wymagająca umiejętności i znajomości technik retorycznych polega na badaniu i refleksji, a nie na publikacji pięknych broszur na kredowym papierze. Lobbyści lubią poszukiwać wsparcia ekspertów i liderów opinii, aby wzmocnić swój punkt widzenia wobec opinii publicznej.

Opisane zjawiska są możliwe dzięki technologiom informacyjnym i komunikacyjnym. Nowe technologie ułatwiają demokratyczne praktyki, pozwalając każdemu obywatelowi wypowiedzieć się, opublikować swoje zdanie bez cenzury. Przybliżają rządzących do rządzonych dzięki bezpośredniej informacji (e-administracja, e-wybory) oraz ułatwienie konsultacji społecznych (e-konsultacje). ${ }^{50}$

Władza internetu, władza sieci powiązana jest jednak z nową formą kontroli społecznej. Jest ona ciągła poprzez otwarte źródła, cyrkulację strumieni informacyjnych, usieciowienie prasy, blogi, fora dyskusyjne. Kontrola jest wzmacniania poprzez możliwość nowej formy ekspertyz - bezpłatnej ekspertyzy on-line. Każdy może być ekspertem w jakiejś dziedzinie (w zależności od zainteresowań, doświadczeń zawodowych czy hobbystycznych). Ekspertami stają się już nawet dzieci, one bowiem, reprezentując „pokolenie sieci”, lepiej sobie radzą z wirtualną rzeczywistością. ${ }^{51}$

\subsubsection{Dostęp i informacja jako kluczowe dla cyberlobbingu}

Z perspektywy analizy metod i technik lobbingowych jednym z kluczowych pojęć wydaje się być pojęcie dostępu, zaproponowane przez Jeremy`ego Rifkina w 2000 roku w pracy Wiek dostępu. Nowa kultura hiperkapitalizmu, w której płaci się za każdą chwile życia. ${ }^{52}$ Dostęp wypiera pojęcie własności i staje się kluczowy dla kapitału intelektualnego, będącego napędem nowej ery. Kapitał intelektualny rzadko podlega wymianie: znajduje się w wyłącznym posiadaniu dostawców, którzy umożliwiają jego dzierżawę lub licencję użytkowania pod pewnymi warunkami. Dzierżawa, wynajem, opłata za wstęp, subskrypcja, członkostwo ,upoważniające do", licencja to zasady rządzące dziś ekonomią. W wersji wikinomii idzie się jeszcze dalej: współwłasność, otwartość, współpraca i współdzielenie to zasady regulujące pracę. Miejsce rzeczy materialnych zajęły pomysły, koncepcje, technologie, idee

\footnotetext{
50 W Polsce obecnie Ministerstwo Gospodarki pracuje nad tą problematyką, przeprowadzono już kilka spotkań z ekspertami i partnerami społecznymi, przedstawiając m.in. w sierpniu 2010 roku multimedialne prezentacje: „Projekt konsultacji on-line” oraz „System konsultacji on-line”. Kolejne spotkanie planowane jest na październik 2011 roku.

51 Pokolenie sieci to wyrażenie zaproponowane przez D. Tapscotta w: Cyfrowa dorosłość. Jak pokolenie sieci zmienia nasz świat, WAiP, Warszawa 2010.

52 J. Rifkin, Wiek dostępu. Nowa kultura hiperkapitalizmu, w której płaci się za każdą chwile życia (2000, wyd. pol. 2003). Jest on również autorem takich prac, jak: The Biotech Century: Harnessing the Gene and Remaking the World (1998), Koniec pracy. Schyłek sity roboczej na świecie i początek ery postrynkowej (1995, wyd. pol. 2001) oraz Europejskie marzenie. Jak europejska wizja przyszłości zaćmiewa American Dream (2004, wyd. pol. 2005).
} 
(know-how). To na prawach autorskich zarabia się dziś najwięcej. Własność ulega radykalnej zmianie: posiadanie jest zastępowane przez dostęp, rynki ustępują miejsca sieciom, wymiana dóbr między sprzedawcami a nabywcami zaczyna ustępować miejsca relacjom krótkiego dostępu w sieciach serwer-klient. Sukces ekonomiczny w gospodarce dostępu zależy w mniejszym stopniu od poszczególnych rynków wymiany dóbr, natomiast ważniejsze jest ustanowienie długotrwałych relacji z klientem, a w wikinomii - ze współuczestnikami. Ale nie należy zapominać, że - jak zauważa Rifkin - jeszcze dekadę temu, w 2000 roku, „ponad połowa ludności na świecie nigdy w życiu nie odbyła zwykłej rozmowy telefonicznej”.

Kluczowa kategoria dostępu wymusiła utowarowienie informacji i jej komercjalizację na masową skalę. Informacja zatem staje się „podstawowym bogactwem” (Drucker), zbiór informacji zaś wiedzą. Mamy do czynienia zarazem z demokratyzacją informacji. ${ }^{53}$ Dostęp do informacji pozwala na tzw. miękką władzę - soft power $\mathrm{w}$ rozumieniu autora pojęcia J. Nye $\mathrm{a}^{54}$

Tworzone są specjalne narzędzia on-line, ułatwiające prowadzenie lobbingu typu grassroots. Są to np. specjalne strony np. gopetition.com, ${ }^{55}$ umożliwiające zbieranie podpisów pod petycjami w 75 krajach. Jest ona obecna na Facebooku, Twitterze, serwisie YouTube. W Polsce podobną rolę spełnia stronawww.petycja.pl. ${ }^{56}$

Zagrożeniem dla cyberlobbingu jest przede wszystkim astroturfing, czyli budowanie pozorów poparcia przez pseudogrupy obywateli, stowarzyszeń w celu wywołania wrażenia masowego poparcia ze strony opinii publicznej. ${ }^{57}$

Z narzędzi on-line do działań lobbingowych i rzeczniczych najchętniej korzystają międzynarodowe organizacje pozarządowe. Taki styl prowadzenia lobbingu przede wszystkim potania koszty działalności, a także kieruje te działania w stronę aktywnych użytkowników sieci.

Skuteczność narzędzi on-line: portali społecznościowych (np. Facebook), mikroblogów (np. Twitter) została sprawdzona w czasie rewolucji w świecie arabskim wiosną 2011 roku. Niektórzy komentatorzy okrzyknęli je nawet „facebookowymi

53 P. Levinson, Miękkie ostrze. Naturalna historia i przyszłość rewolucji informacyjnej, Muza, Warszawa 1999.

54 J. Nye, Soft power. Jak osiagnać sukces w polityce światowej, WAiP, Warszawa 2004.

55 http://www.gopetition.com/

56 Petycje.pl (serwis) umożliwiają wszystkim zainteresowanym (autor/autorzy) bezpłatne napisanie i opublikowanie na stronach serwisu własnych dokumentów. Po publikacji są one udostępniane wszystkim osobom odwiedzającym serwis (użytkownik/użytkownicy), którzy mogą zapoznać się z nimi i ewentualnie odnieść do ich treści. Dokumenty mogą być kierowane do urzędów, firm, organizacji lub do osób prywatnych zajmujących stanowiska publiczne (adresat/ adresaci). Po opublikowaniu dokumentu na wniosek autora wysyłamy wiadomość e-mail do adresata informującą o publikacji. Autor z kolei jest odpowiedzialny za inne formy dostarczenia dokumentu do adresata. Wszystkie opublikowane dokumenty podlegają weryfikacji i mogą zostać usunięte w przypadku naruszenia zasad regulaminu lub obowiązującego prawa. Za: http://www.petycje.pl/petycjeCoOferujemy.php

57 http://en.wikipedia.org/wiki/Astroturfing (dostęp 12.10.2011). 
rewolucjami", ${ }^{8}$ co jest jednak pewnym uproszczeniem, gdyż nawet najlepsze narzędzie nie zastąpi idei i programu zmiany, który może zaproponować tylko człowiek. Rewolucje w krajach arabskich pokazały jednak, w jaki sposób egalitarne wspólnoty podejmowały się różnorodnych zadań i dzieliły się rezultatami swojej pracy. Wspólnoty te charakteryzuje decentralizacja hierarchii (brak liderów), a jednocześnie nawet największe zagromadzenia czy manifestacje były doskonale zarządzane.

\section{Podsumowanie: cyberlobbing - czy kres tradycyjnych modeli lobbingu?}

Sytuacja kryzysu powoduje, że wiele sektorów gospodarki dokonuje cięć w swoich budżetach, ograniczając wydatki. Jak pokazują wyniki badań, ograniczenia dotyczą w pierwszej kolejności działalności promocyjnej, public relations, szkoleniowej. W sektorze lobbingowym oszczędności można szukać, zmieniając strategię i taktykę prowadzenia kampanii lobbingowych. Nowe media i technologie dają możliwość obniżenia kosztu kampanii, przy ich międzynarodowym czy wręcz globalnym charakterze. Kampanie te noszą nazwę kampanii cyberlobbingowych.

Należy jednak pamiętać, o czym przypominają eksperci, że w sytuacjach dziejących się na forum europejskim czy międzynarodowym, z udziałem wielu aktorów, lobbing klasyczny, z przewagą lobbingu bezpośredniego, opartego na kontaktach „twarzą w twarz”, wydaje się być nie do zastąpienia. Należy się zgodzić z ekspertem w sprawach lobbingu na forum Unii Europejskiej, Rinusem van Schendelenem, że „niezależnie jednak od wszystkich nowości i ułatwień technologicznych pozyskiwanie informacji nadal jest kwestią zaufania i kontaktów. W niektórych przypadkach nowoczesne technologie w zasadzie nie mają żadnego zastosowania. Lobbowanie w celu zawarcia układu bądź kompromisu wymaga zindywidualizowanego podejścia, do którego fizyczne spotkanie jest niezbędne. Początkowo pozornie banalne pytanie na temat miejsca lobowania okazało się jednak istotne w kontekście zapewnienia warunków do wygranej”. 59

Także ukazujące się coraz liczniej świadectwa uczestników rewolucji arabskich z wiosny 2011 roku pokazują, że aspekt technologiczny, jakim jest internet, to nie wszystko. Jak mówił w wywiadzie egipski grafficiarz Ganzeer, „Internet to tylko

58 Por. film na portalu Przegląd Nato, http://www.nato.int/docu/review/2011/Social_Medias/Arab_Spring/PL/ index.htm

59 R. van Schendelen, Machiavelli w Brukseli. Sztuka lobbingu w Unii Europejskiej, Gdańskie Wydawnictwo Psychologiczne, Sopot 2006, s. 220. 
narzędzie, które nam ułatwiło robotę. Nie byłoby Facebooka czy komórek - użylibyśmy gołębi pocztowych. W Polsce w 1989 jakoś zrobiliście rewolucję bez internetu”. ${ }^{00}$

\section{Evolution of lobbying models: the influence of knowledge and information-based economy}

The text analyzes institutionalization of lobbying and its ties with democracy, and compares models of lobbying (pluralistic - model typical for the USA, UK, neo-corporativistic - model typical for Western Europe and Poland and the EU model). Then, lobbying is showed in the context of changes caused by the development of knowledge and information-based economy, particularly wikinomy - economy based on cooperation. The development of new technologies and the rules of global cooperation, which are the key elements of this economy, influence the creation of new lobbying strategies. This is the cause of evolution of contemporary models of lobbying in the direction of grassroots lobbying which can take different forms: from mass protests to network and internet actions. This is now called cyberlobbying and can be applied to different forms of lobbying: political, economic and social.

\section{L'évolution des modèles de lobbying - l'impact d'une économie fondée sur l'information et la connaissance}

Larticle analyse l'institutionnalisation du lobbying et de ses liens avec la démocratie. Lauteur présente aussi la comparaison des modèles de lobbying (le modèle pluraliste typique pour les Etats-Unis et le Royaume-Uni, le modèle néo-corporativistic typique pour l'Europe occidentale, la Pologne et le modèle typique pour l'UE). Ensuite, le lobbying est presenté dans le contexte des changements causés par le développement de nouvelle économie basée sur l'information et la connaisance. Sa forme particulière est wikinomie - léconomie basée sur la coopération. Le développement de nouvelles technologies et les principes de la coopération mondiale, qui sont des éléments clés dans cette économie, influent sur lémergence de nouvelles stratégies en matière de lobbying. Cela provoque lévolution des modèles précédents de lobbying vers grassroots lobbying, qui prend des formes diverses:

60 Jak namalowałem rewolucję, wywiad W. Szabłowskiego z egipskim grafficiarzem Gazneerem, „Gazeta Wyborcza” dodatek „Duży Format”13.10.2011, http://wyborcza.pl/1,99218,10465623,Jak namalowałem rewolucje.html (dostęp 20.062012) 
à partir de manifestations de masse pour les actions à Internet. C'est ce qu'on appelle aujourd'hui cyberlobbying et peut être appliqué à différentes formes de lobbying: politique, économique et social. 